ISSN 1994-7836 (print)

ISSN 2519-2477 (online)

УДК 582.724.1

Article info

Received 03.04.2017 p.

\section{ONTOMORFOHENESIS HIPPOPHAE RHAMNOIDES L. IN CONDITIONS OF RIGHT-BANK FOREST-STEPPE OF UKRAINE}

Ontomorfohensis Hippophae rhamnoides L. was investigated in natural conditions in Ukraine and in a culture at the National Arboretum "Sofiyivka", NAS of Ukraine. As a result of observations of individuals it was found that the annual cycle of $H$. rhamnoides conforms to seasonal climatic fluctuations. During the plants growing within a large life-cycle, four ages periods and nine age classes were allocated: latent period (sm), pre generative period ( $\mathrm{p}, \mathrm{j}, \mathrm{im}, \mathrm{v})$, generative period ( $\mathrm{g} 1, \mathrm{~g} 2, \mathrm{~g} 3)$ and period of old age (ss, s). Separations of ontogenesis periods are qualitatively different stages based on the consistent implementation at the period of various portions of the genetic information on a gradual phased deployment of genetic information development program. Each of the following periods of ontogeny has specific physiological properties and morphological features and covers as the establishment and the growth of new structures so physiological changes that prepare the emergence of these structures. The features of $H$. rhamnoides in different stages of ontogeny were described. Updated diagnostic features of age classes were given. It was established that individuals differ in pre generative period mainly by morphometric parameters of sprout system and root formation, young, mature and old generative individuals by reproductive development. A number of adaptive features were identified during onto morphogenetic study: simultaneous passing periods and stages ontomorfohenesis; with the increasing of light exposure and temperature leaf size of plates increases also; flowering does not occur at the same time and takes a different number of days of various lengths; possibility of natural vegetative reproduction of plants to form a flower bed. The obtained results expand the understanding of the biology of the studied species, especially the formation of sprout system and root formation that will help to identify the age state of plants and the development of rational methods of cultivation and breeding.

Keywords: age period; age states; shoots growth; flower formation; fructification; root formation.

Introduction. Preservation and enrichment of biodiversity through the introduction and cultivation of plants is one of the priorities of the botanical gardens. Rare fruit crops that have agronomic properties deserve special attention. Sea buckthorn (Hippophae rhamnoides L.) is traditionally regarded as medicinal, edible, decorative, erosion, nitrogen fixing plant. In Ukraine, it grows in south-western areas in the valleys of the Dniester, Danube and their tributaries. It often occurs after a wild plant cultivation in gardens, arboretum. This is a typical Eurasian, dioecious, anemophilous type of plant Elaeagnaceae Lindl. This species belongs to the typical mesophytic, but with the characteristic xeromorphic above-ground structure of bodies (Shpytalnaia, 2006). According to the classification of life forms K. Raunkiyer it is woody phanerophytes, according to the classification of types biomorphic I. H. Serebryakov it belongs to the department of woody plants, such as - deciduous shrub (Serebriakov, 1954). According to L. S. Sahalakova \& L. K. Bardonova (2011) it may have two life forms: singletree and shrub without branching underground. According to the morphological features it is a polymorphic type, which has a pronounced variability, represents a variety of shapes and varieties with different qualitative and quantitative criteria.

A detailed study of the biological characteristics, especially ontomorfohenesis of plants is particularly important because the data can establish the level of adaptive capacity, resilience and life of plants in conditions of introduction. The literature has accumulated significant factual and theoretical material about ontogeny of woody plants, resulting in the physiological, morphological, forestry, population ontogenetic studies. Their result was the understanding of the factors and mechanisms of morphological and functi- onal changes at various stages of ontogeny. Most of the works devoted to the study of age-related conditions of plants in natural conditions, while the ontogeny of plants under introduction less, mainly in conditions as close to nature (Vdovyna, 2009; Sahalakova \& Bardonova, 2011). Therefore, the study of features ontomorfohenesis of $H$. rhamnoides and especially its varieties and age-classes in conditions of introduction is important. This will improve the efficiency of selection of promising plant for practices and commercial effectiveness of variety.

The aim - to determine the features ontomorfohenesis of $H$. rhamnoides plants in natural conditions in Ukraine and in a culture at the National Arboretum "Sofiyivka", NAS of Ukraine.

Materials and methods of research. Object is plant varieties $H$. rhamnoides - Solodka zhinka, Lybid, Kyivskyi yantar, Alei, Chuiska, Dar Katuni and Vitaminna. Morfo Biological features were studied at the National Arboretum "Sofiyivka", NAS of Ukraine. Phenological observations were carried out by (Methodology of phenological observations in the botanical gardens of the USSR, 1975). Selection of ontogenetic states and ontomorfohenesis study were carried out by conventional methods (Recommendation on the study of ontogenesis of introduction plants in the botanical gardens of the USSR, 1990) based on a complex of morphological and biological characteristics. Description of age classes were performed by measuring the age of each 10-30 individuals on two key areas - seed (sowing seeds in boxes with the following planting plants in the open ground) and vegetative plantings (engraftment of the green stem cuttings).

Research results. As a result of observations of individuals it was found that the annual cycle of $H$. rhamnoides

Цитування за ДСтУ: Миколайко І. І. Онтоморфогенез Hippophae Rhamnoides L. в умовах Правобережного лісостепу України / І. І. Миколайко // Науковий вісник НЛТУ України. - 2017. - Вип. 27(3). - C. 53-56

Citation APA: Mykolaiko, I. І. (2017). Ontomorfohenesis Hippophae rhamnoides L. in Conditions of Right-Bank Forest-Steppe of Ukraine. Scientific Bulletin of UNFU, 27(3), 53-56. Retrieved from: http://nv.nltu.edu.ua/index.php/journal/article/view/346 
conforms to seasonal climatic fluctuations (Mykolaiko, 2014). During the plants growing within a large life-cycle, four ages periods and nine age classes were allocated: latent period $(\mathrm{sm})$, pre generative period $(\mathrm{p}, \mathrm{j}, \mathrm{im}, \mathrm{v})$, generative period $\left(g_{1}, g_{2}, g_{3}\right)$ and period of old age (ss, s).

The latent period $(\mathrm{sm})$ starts from the seed formation and its independent existence at rest period. Fruit - oval drupe. Seeds are brown, shiny, ovoid form, elongated and slightly flattened, with characteristic longitudinal grooves on both sides. Revealed that the seeds of the studied plants vary in size (length $-4,30-4,76^{ \pm 2,6} \mathrm{~mm}$, width $-1,42-1,76^{ \pm 1,4} \mathrm{~mm}$ ) and weight of 1000 seeds $\left(0,58-0,79^{ \pm 4,2} \mathrm{~g}\right)$, which has diagnostic value.

Pre generative period of time (1-3 years) includes prejuvenile (p), juvenile (j), imaturnyy (im), virhinilnyy (v) age-related conditions.

Prejuvenile (p) age condition includes two sub phases plantlets and shoots. The plantlets appear on the $7^{\text {th }}-8^{\text {th }}$ day and shoots on the $10^{\text {th }}-15^{\text {th }}$ day. Similarity of seed is almost $78 \%$. Germination of seed is underground. The under cotyledon part is pale green, then it turns fulvous; it is nude 20-40 mm long, cylindrical, passes unnoticed in the taproot. The cotyledons are oval, nude and succulent, greenish-mat on the top and yellow on the bottom, rounded at the top, and column-wide at the base. Cotyledons gradually transformed into a stalk. As the shoots grows cotyledons increase in size: during germination, they have a length of $5,5 \mathrm{~mm}$ and a width of $2,5 \mathrm{~mm}$, and reach a length of $13 \mathrm{~mm}$ and a width of $5,5 \mathrm{~mm}$ in the current state to the drying time. Their shape changes from oval-ovate to ellipsoidal or even reverse-ovoid form. Stalk sizes changes to 1,5-2,0 mm. Sizes of cotyledons of some individual plants vary considerably depending on the size of the seed. After 8-10 days first pair of leaves appears. At the age of 2 weeks hypocotyls stretches to $1,5-2,5 \mathrm{~cm}$, and the general size of the sprout is $3,5-4,5 \mathrm{~cm}$. The above cotyledon interstices are cylindrical $9 \mathrm{~mm}$ long. At the age of 5 weeks cotyledon leaves reach their maximum size: about $15 \%$ of the plantlets are characterized by the second pair of leaves; leaf size: the length of the first pair is $12-15 \mathrm{~mm}$, width is $5 \mathrm{~mm}$; the second is $23-25 \mathrm{~mm}$ and a width is $5,5 \mathrm{~mm}$. The seedlings reach a height of $5-10 \mathrm{~cm}$.

Juvenile age condition $(j)$ - is visible on the $60^{\text {th }}$ day and lasts for a year. It is the initial phase in the growing of aerial parts and forming the secondary root system. There is a third pair of leaves $-25-30 \mathrm{~mm}$ long and 6,5 mm wide. At the end of June, if here are 4-5 pairs of opposite leaves, cotyledons turn yellow, wither and begin to fall off one by one, leaving only traces of attachment. The first 4-5 pairs of leaves are opposite, oblong, whole and entire on short $(1 \mathrm{~mm})$ stalks, serving well below with the median vein, densely covered, especially downside, shorted stalk with silver-gray color. At the time of growing completion juvenile samples are characterized by availability of 6-8 real pairs of leaves with a size $-20-36 \mathrm{~mm}$ and a width of 7,1 mm. Juvenile plant has one upright (orthotropic) herbaceous sprout, $12-43 \mathrm{~cm}$ tall. The type of increase is monopodial. The root system is rod, 20-60 cm long.

Imaturnyy age condition (im) - is on the second year its duration is one year. Its characterized by the first sprout branching. The stalk is stiff. Each newly formed leave is larger than the previous one but smaller than adult plants.
The root system gets more signs of fibrous rod-type as a result of intensive formation of roots of different categories. Lateral roots branch out actively. Their total length is about $130 \mathrm{~cm}$.

Virhinilnyy age condition $(\mathrm{v})$ - is on the third year and continues to the end of the fourth year of growing. Plants at virhinilnyy age reach a height of 100-175 cm, with numerous stiff side sprouts (5-6 sprouts of the first order, each of which formed partly stiff 1-2 sprouts of the second category). Typical adult plant's leaves are narrowly lanceolate with 4,5-8 cm length. At this period there is a suspension of active growth of roots of the first category, which reach $40-55 \mathrm{~cm}$, roots of other categories are from 5 to $12 \mathrm{~cm}$ long.

With vegetative way growing prejuvenile (p) age begins with callus formation one week after planting the cuttings in terms of finely dispersed moisture and continues 10-12 days to mass root formation and its formation occurs on the $18^{\text {th }}-20^{\text {th }}$ day. Passing to the juvenile age as seed so cuttings plantations reated with the phase of the $3^{\text {rd }}-4^{\text {th }}$ leaf and with the beginning of main root branching, at imaturnyy age with the formation of the $5^{\text {th }}-7^{\text {th }}$ leaves and with the development of roots of different categories, at virhinilnyy age with the development of the $8^{\text {th }}-11^{\text {th }}$ leaves, with forming of small orthotropic rhizomes in the sprout basis, with the roots formation of the third category.

Generative period combines three onto morphogenetic conditions. Young generative period (4-9 years) $\left(\mathrm{g}_{1}\right)$. This period is the replacement for sprout formation on sympodial. Last year's sprouts end with thorns. The following year, the growth of the main sprout in height is due to lateral buds that are situated lower than thorns from which secondary 2-3 major subsidiaries skeletal sprouts are developing. Dying of lower lateral sprouts happen. Whorl is formed. Sprouts have generative and vegetative buds. Flower buds are laid mainly on the biennial sprouts. The fruits have a wide range of variability, mainly various fetal colors, shape, size, stem length and their number in fruit bud. As a result of research of 100 fruit sample varieties Kyivskyi yantar and Solodka zhinka had a weight of 0,39 to 0,63 grams (2,6 to $4,3 \%$ by weight of ripe fruits) Dar Katuni and Lybid - from 1,1 to $2,6 \mathrm{~g}(3,4-7,3 \%)$ Chuiska and Vitaminna $-3,2-4,1 \mathrm{~g}(5,4-7,4 \%)$. Visually fruit varieties of $H$. rhamnoides in the immature state are firm, bright green color; during the maturation their color varies from light orange (Solodka zhinka Dar Katuni, Lybid), bright orange (Chuiska, Vitaminna) to yellow-red color (Kyivskyi yantar). Consumptive ripening occurs on average in early August for plant varieties like Kyivskyi yantar and Solodka zhinka, in the second week of August for Dar Katuni and Lybid and on the third week of August for Vitaminna and Chuiska. Roots are thick, rope-like, long, are placed horizontally $60-80 \mathrm{~cm}$ from the soil surface. Plant height is 1,2-2,0 $\mathrm{m}$, the dimensions of leaves: length $-40,0-80,4 \mathrm{~mm}$, width $7,10 \mathrm{~mm}$ diameter of crown - from 0,9 to $1,5 \mathrm{~m}$.

Middle-generative period (10-14 years) $\left(\mathrm{g}_{2}\right)$. During this period, the plant varieties of $H$. rhamnoides are especially productive. In the root neck the crown consists of uneven skeletal axes of different diameters. There is dying of lower branches and whorls, sprouts out the top of the trunk continue to branch out. Not a large number of root sprouts are 
formed, due to which a vegetative reproduction happens. Plant height is $1,8-2,4 \mathrm{~m}$, diameter of the crown is $2,5 \mathrm{~m}$.

Old generative period (15-19 years) $\left(\mathrm{g}_{3}\right)$. Ability for creating of sprouts reduces and the length of annual outgrowths decreases. Dying of partial skeletal axes happens. Vegetative reproduction by using root sprouts stops. Fruiting greatly reduces.

Post generative period (20-25 years) is divided into two sub-periods: subsenylnyy (ss) and senylnyy (s). Their characteristic feature is the acquisition of specific morphogenetic characteristics and reduction of physiological activity. The plants gradually lose their ability to flowering, fruiting and reproduction. A complete dying of species is observed.

Conclusions. The studies found that ontomorfohenesis of $H$. rhamnoides in Right Bank Forest-Steppe of Ukraine is practically the same. The polymorphism on morphological parameters of plants in different periods of life is observed: average height, size of leaf plate, crown's diameter and length of thorns. Separations of ontogenesis periods are qualitatively different stages based on the consistent implementation at the period of various portions of the genetic information on a gradual phased deployment of genetic information development program. Each of the following periods of ontogeny has specific physiological properties and morphological features and covers as the establishment and the growth of new structures so physiological changes that prepare the emergence of these structures. A number of adaptive features were identified during onto morphogenetic study: simultaneous passing periods and stages ontomorfohenesis; flowering does not occur at the same time and takes a different number of days of various lengths; possibility of natural vegetative reproduction of plants to form a flower bed.

\section{References}

Metodyka fenolohycheskykh nabliudenyi v botanycheskykh sadakh SSSR (1975) [Methodology of phenological supervisions is in the botanical gardens of the USSR]. Moscow: HBS. [in Russian].

Mykolaiko, I. I. (2014). Fenolohichni aspekty rozvytku henotypiv Hippophae rhamnoides L. v Pravoberezhnomu Lisostepu Ukrainy [Phenological aspects of development of genotypes of Hippophae rhamnoides L. in Right-bank to Forest-steppe of Ukraine]. In Naukovyi visnyk NLTU Ukrainy, 24(2), 62-68. [in Ukrainian].

Sahalakova L. S., \& Bardonova L. K. (2011). Ontohenez Hippophae Rhamnoides [Ontogenesis of Hippophae Rhamnoides]. In Vesnyk $B H U, 4,88-92$. [in Russian].

Serebriakov, Y. H. (1954). O morfoheneze zhyznennoi formы dereva u lesnыkh porod srednei polosы Evropeiskoi chasty SSSR [About the morphogeny of life-form of tree at the forest breeds of middle stripe of European part of the USSR]. In Biulleten MOYP, otd. Byolohyy, LIX (1), 53-68. [in Russian].

Shpytalnaia, T. V. (2006). Byolohycheskye osobennosty ontoheneza oblepykhy krushynovydnoi (Hippophae rhamnoides L.) pry yntroduktsyy $\mathrm{v}$ Belarusy [Biological features of ontogenesis of seabuckthorn (Hippophae rhamnoides L.) at introduction in Belarus]. Abstract of candidate dissertation for biological sciences. [in Russian]. Mynsk. [In Belorus]

Sykura, Y. Y., \& Syrytsa, L.T. (1990). Rekomendatsyy po yzuchenyiu ontoheneza yntrodutsyrovanukh rastenyi v botanycheskykh sadakh SSSR [Recommendation on the study of ontogenesis of introduction plants in the botanical gardens of the USSR]. Kyiv. [in Russian].

Vdovyna, T. A. (2009). Vozrasnaia struktura dykorastushchykh populiatsyi oblepykhy y prodolzhytelnost zhyzny rastenyi v pryrode y kulture [The age-related structure of populations of sea-buckthorn and life-span of plants are in the wild and culture]. In Yzvestyia NAN RK. Seryia byolohycheskaia y medytsynskaia, 2, 47-79. [in Russian]

\section{И. И. Миколайко}

\section{OНTОМОРФОГЕНЕЗ НIPРОРНАЕ RHAMNOIDES L. В УСЛОВИЯХ ПРАВОБЕРЕЖНОЙ ЛЕСОСТЕПИ УКРАИНЫ}

Исследован онтоморфогенез Hippophae rhamnoides L. в естественных условиях в Украине и в условиях культуры в Национальном дендрологическом парке "Софиевка" НАН Украины. Установлено, что годовой цикл развития H. rhamnoides согласуется с сезонными климатическими колебаниями. За время выращивания растений в пределах большого жизненного цикла выделены четыре возрастные периоды и девять возрастных состояний: латентный период (sm), догенеративный период (p, j, im, v), генеративный период (g1, g2, g3) и период старости (ss, s). Разделение онтогенеза на периоды основан на последовательной реализации во времени различных порций генетической информации, на постепенном поэтапном развертывании наследственной информации программы. Каждый из последовательных периодов онтогенеза имеет специфические физиологические свойства и морфологические признаки и охватывает как образование и рост новых структур, так и физиологические изменения, которые готовят возникновения этих структур. Описаны особенности H. rhamnoides на разных этапах онтогенеза. Приведены уточненные диагностические признаки возрастных состояний. Установлено, что особи в догенеративный период отличаются преимущественно по морфометрическим показателям побеговой системы и корнеобразованию, молодые, зрелые и старые генеративные особи - по репродуктивному развитию. Выявлен ряд адаптационных особенностей: одновременное прохождение периодов и стадий онтоморфогенеза; цветение наступает не сразу и продолжается разное количество дней; возможность естественного вегетативного размножения растений с образованием куртин. Полученные результаты исследований расширяют представления о биологии изучаемого вида, особенности корнеобразования, формирования побеговой системы, что будет способствовать идентификации возрастных состояний растений, а также разработке рациональных приемов выращивания и размножения.

Ключевые слова: возрастные периоды; возрастные состояния; рост побегов; цветение; плодоношение; корнеобразование.

I. І. Миколайко

\section{OHТОМОРФОГЕНЕЗ HIPPOPHAE RHAMNOIDES L. В УМОВАХ ПРАВОБЕРЕЖНОГО ЛІСОСТЕПУ УКРАЇНИ}

Досліджено онтоморфогенез Hippophae rhamnoides L. у природних умовах в Україні та в умовах культури у Національному Дендрологічному парку "Софіївка" НАН України. Встановлено, що річний цикл розвитку H. rhamnoides узгоджується із сезонними кліматичними коливаннями. За час вирощування рослин у межах великого життєвого циклу виділено чотири вікові періоди та дев'ять вікових станів: латентний період (sm), догенеративний період (p, j, im, v), генеративний період (g1, g2, g3) та період старості (ss, s). Розділення онтогенезу на періоди грунтуються на послідовній реалізації у часі різноманітних порцій генетич- 
ної інформації, на поступовому поетапному розгортанні спадкової інформації програми розвитку. Кожний із послідовних періодів онтогенезу має специфічні фізіологічні властивості і морфологічні ознаки та охоплює як утворення і ріст нових структур, так і фізіологічні зміни, що готують виникнення цих структур. Описано особливості H. rhamnoides на різних етапах онтогенезу. Наведено уточнені діагностичні ознаки вікових станів. Установлено, що особини у догенеративний період відрізняються переважно за морфометричними показниками пагонової системи та коренеутворенням, молоді, зрілі і старі генеративні особини - за репродуктивним розвитком. Виявлено низку адаптаційних особливостей: одночасне проходження періодів і стадій онтоморфогенезу; квітування настає не одночасно і триває різну кількість днів; можливість природного вегетативного розмноження рослин з утворенням куртин. Отримані результати дослідження розширюють уявлення про біологію досліджуваного виду, особливості коренеутворення, формування пагонової системи, що сприятиме ідентифікації вікових станів рослин, а також розробленню раціональних прийомів вирощування і розмноження.

Ключові слова: вікові періоди; вікові стани; ріст пагонів; квітування; плодоношення; коренеутворення.

Інформація про автора:

Миколайко Ірина Іванівна, канд. біол. наук, доцент, Уманський державний педагогічний університет ім. Павла Тичини, м. Умань, Україна. Email: irinamikolaiko@i.ua 